\title{
Current knowledge and research perspectives of the shell formation process in the genus Arcella (Arcellinida: Amoebozoa)
}

\author{
Alfredo L. Porfírio-Sousa and Daniel J.G. Lahr \\ Department of Zoology, Institute of Biosciences, University of São Paulo, Brazil
}

| Submitted January 17, 2020 | Accepted February 28, 2020 ||

\begin{abstract}
Summary
Arcellinida is an Amoebozoa lineage characterized by the presence of an external shell. A comprehensive cyto-morphological description of the shell structure and formation (thecagenesis) process has been generated due to publications in the time span of more than a century. Recently, few works have advanced our understanding of the thecagenesis process or discussed this rich literature; however, several aspects of the shell formation and structure are still puzzles, as remains the relationship between genes and shell formation morphogenesis. Here we present an overview of the literature about shell formation and structure, focusing on the genus Arcella, the best-studied lineage. We show that some aspects regarding shell formation are still open questions. Moreover, based on the current knowledge, we can establish new frameworks, to address such issues as the origin and evolution of the shell in Arcellinida.
\end{abstract}

Key words: testate amoebae, arcellinids, thecagenesis, morphogenesis of amoebae test, phenotypic plasticity, shell origin, shell evolution

\section{Introduction}

Arcellinida is the most diverse group of testate amoebae (currently with around 687 nominal species) - the organisms characterized by the presence of an outer shell (test) (Kosakyan et al., 2016). The structure and formation (thecagenesis) process of Arcellinida shells have remained a puzzle for many years and intrigued generations of researchers (Moraczewski, 1971; Netzel, 1971; Mignot and Raikov, 1990). Diverse studies present a comprehensive interpretation of Arcellinida shell, primarily using the genus Arcella Ehrenberg as an example (Moraczewski, 1971). The focus on this genus is largely due to the abundance of its representatives in diverse freshwater environments, their capability to grow in laboratory cultures, and vast literature. Together, these characteristics define Arcella as a promising study model for Arcellinida.

The shell of Arcella was identified for the first time in 1830, in the original description of Arcella vulgaris (Ehrenberg, 1830). Since this initial observation and the first discussion of its structure by Wallich (1864), the structure and formation process of the shell in Arcella received special attention of several authors during the time span of more than a

doi:10.21685/1680-0826-2020-14-1-1 
century. Moraczewski (1971) presented an overview of the literature comprising results of such studies in 1830 through 1967. During this period, 17 studies discussed the shell structures and their formation process in Arcella, based on light and electron microscopy (Moraczewski, 1971). From 1971 to 1990, seven studies advanced our understanding of shell formation in the genus Arcella (Moraczewski, 1971; Netzel, 1971, 1975a, 1975b, 1980; Netzel and Grunewald, 1977; Mignot and Raikov, 1990). Recently, Pchelin (2010) and Volkova and Smirnov (2016) discussed shell formation during test regeneration in Arcella.

Here we present a timeline of the literature that deals with shell structure and its formation process in Arcella. We briefly present the studies from 1864 to 1967, discussed by Moraczewski (for a detailed discussion please check Moraczewski, 1971), and provide an overview of the studies between 1971 and 2016. Additionally to the extensive reference list and review of articles regarding shell formation, we present a general overview of many studies that elucidated the thecagenesis in the genus Arcella as we understand this process now. We summarize the current viewpoints on shell formation and structure in Arcella based on a historical retrospective. Finally, we present our understanding of the thecagenesis process, disclose some gaps in the current knowledge, and propose a research framework that would advance this field of biological studies.

\section{Literature timeline}

To date, over 25 studies comprise the key literature that discusses the shell structure and formation process in Arcella (Fig. 1). From 1864 to 1928, researchers focused on the description of the general structure of the shell, enabled by light microscopy (Fig. 1); several interpretations of the shell formation process were derived from those descriptions (Moraczewski, 1971). This period was followed by 35 years, between 1928 and 1963, when literature was focusing mainly on ecology of these organisms, but not on the nature of their shell (Fig. 1; Moraczewski, 1971). Cambar et al. (1963) renewed the discussion of shell structure and introduced the use of electron microscopy, describing the external structure of the Arcella shell (Fig. 1). In the following studies, researchers applied both light and electron microscopy to shed light on the shell formation and structure (Fig. 1). Charret and Vivier (1964), and Charret (1967) presented the first scanning electron microscopy micrographs of sections of Arcella's shell and cytoplasm (Fig. 1). Moraczewski (1971) published the first study describing direct evidence of the process of shell formation (Fig. 1); he presented several possible interpretations of the shell formation process, based on his observations of tangential sections of Arcella's cells and the previous literature. The time span from 1971 to 1990 was a productive period for the description of the thecagenesis process and shell structure as we understand them now (Fig. 1). Harald Netzel, a remarkable contributor to Arcellinida shell studies, published five articles describing the shell and formation process in different species of the genus Arcella (Fig. 1; Netzel, 1971, 1975a, 1975b, 1980; Netzel and Grunewald, 1977). In 1990, Mignot and Raikov contributed to the description established by $\mathrm{H}$. Netzel and coauthors; they presented additional observations and interpretations based on several tangential sections of Arcella vulgaris during shell formation, which together represent the complete process (Mignot and Raikov, 1990). It was only recently, 20 years after Mignot and Raikov's publication, that two more studies dealt with the shell formation process: Pchelin (2010), and Volkova and Smirnov (2016) studied shell formation during test regeneration in Arcella vulgaris (Fig. 1). Both studies demonstrated that Arcella is capable of regenerating its shell, once deprived of this structure by in vivo dissection (Pchelin, 2010; Volkova and Smirnov, 2016). To date, however, none of the studies has discussed the possible molecular process and genes underlying shell formation, a topic already pointed out more than 40 years ago by Netzel and Grunewald (1977).

\section{Shell formation process followed by cell divi- sion in Arcella}

Arcella has a general mechanism of thecagenesis: arrangement and secretion (extrusion) of thecagenous granules derived from the Golgi apparatus (Mignot and Raikov, 1990). The first evidence of shell formation is the appearance and concentration of Golgi-derived thecagenous granules in the cytoplasm (Fig. 2 A; Netzel, 1971, 1975a, 1975b; Netzel and Grunewald, 1977; Mignot and Raikov, 1990). The granules concentrate near the cell membrane in a cytoplasmic region close to the shell 

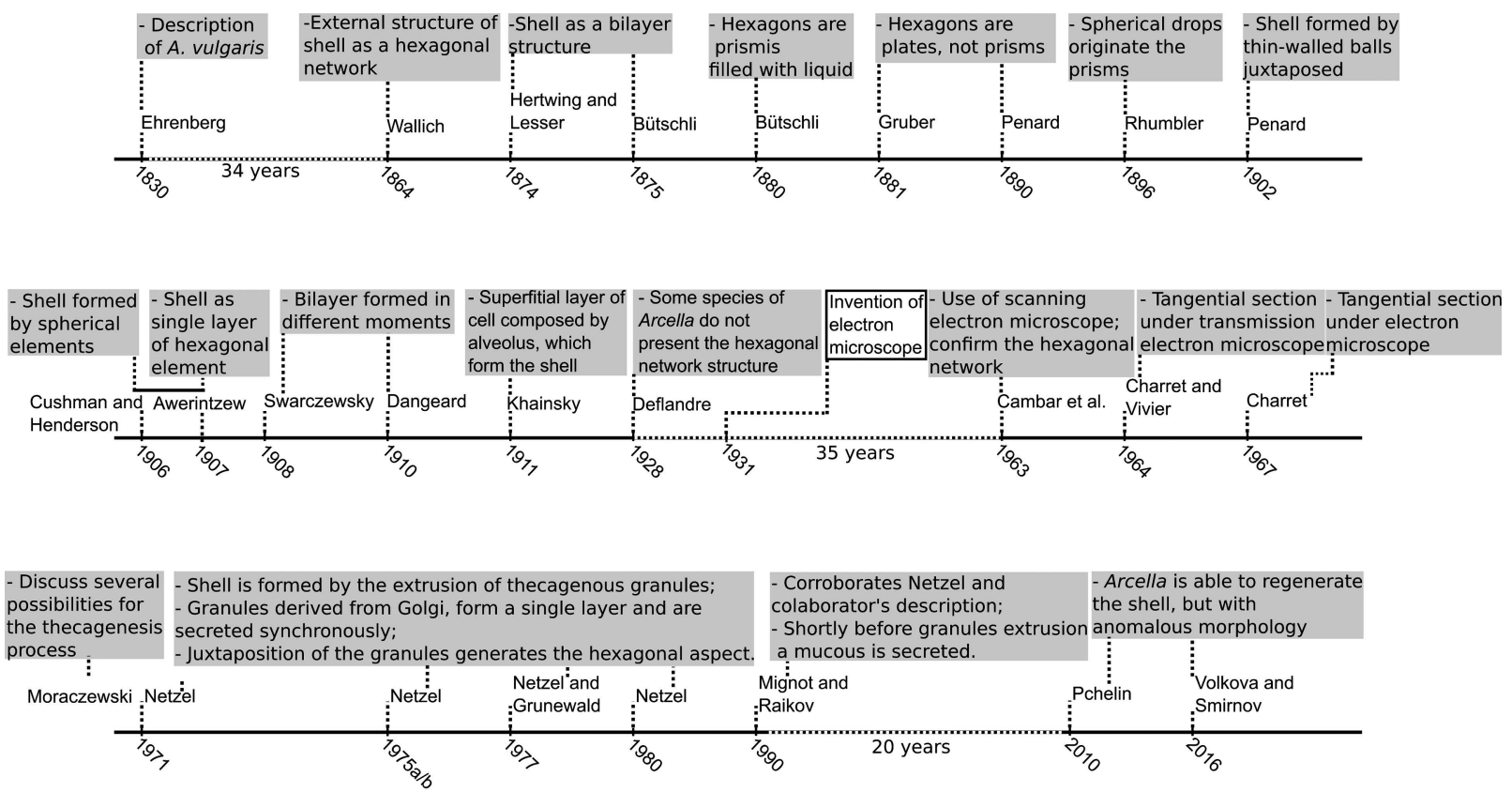

Fig. 1. Timeline with an overview of the literature that discusses the shell structure and thecagenesis process focusing in the genus Arcella. Time scale in years; dashed time scale lines represent long periods lacking studies about shell structure and formation. Gray boxes present some key ideas and contributions presented by each author, which are relevant to the present study.

aperture; this region is the site formation of the cell division bud (Netzel and Grunewald, 1977), later referred to as thecagenous bud (Mignot and Raikov, 1990), which grows through the shell aperture (Fig. 2 A-B). Netzel (1971, 1977) demonstrated that the granules become arranged in a single layer and are synchronously secreted as shell formation proceeds, forming an amorphous structure at the edge of the cell membrane (Fig. 2 C); shortly, a defined shape of the granules structures is observed (Fig. 2 D). The granules extrusion is followed by an abrupt thecagenous bud growth and cytoplasmic flux from the old shell towards the new (daughter) shell; the shell is externalized and covered by a special type of pseudopod, the pseudopodial dome (Fig. 2 E; Netzel, 1971; Mignot and Raikov, 1990). This cytoplasmic flux determines the general size and morphology of the daughter shell (Fig. 2 E). Once this shape is determined, the cytoplasmic flux between both shells does not modify the shell morphology anymore; this cytoplasmic flux is followed by cytokinesis, the final stage of Arcella fission (Fig. 2 F).

In vivo, as shown by light microscopy, the first evidence of shell formation is the appearance of the thecagenous bud (Fig. 3 A-B; Netzel, 1969; Netzel and Grunewald, 1977). This bud grows abruptly and the shell becomes visible, covered by the pseudopodial dome (Fig. 3 C; Netzel, 1969; Netzel and Grunewald, 1977); a cytoplasmic flux towards the daughter shell determines its shape (Fig. 3 D; Netzel, 1969; Netzel and Grunewald, 1977). Briefly, it is possible to identify an abrupt retraction of the pseudopodial dome (Fig. 3 D; Netzel, 1969). An intense cytoplasmic flux is observed between both shells; no modification of the daughter shell morphology is observed (Fig. 3 E; Netzel, 1969; Netzel and Grunewald, 1977). Finally, the cells divide by cytokinesis (Fig. 3 F-G; Netzel, 1969) and two separated individuals are observed (Fig. 3 H-I; Netzel, 1969).

\section{Shell formation process followed by exuvia- tion}

Thecagenesis is not always followed by cell division; for example, exuviation involves a shell formation process that is not followed by cell division (Penard, 1902; Hegner, 1919, 1920). During this process, a shell is built and the cell moves to the new shell, leaving the older one empty; in some other cases, the newly formed shell is left empty (Penard, 1902; Hegner, 1919, 1920). Hegner 

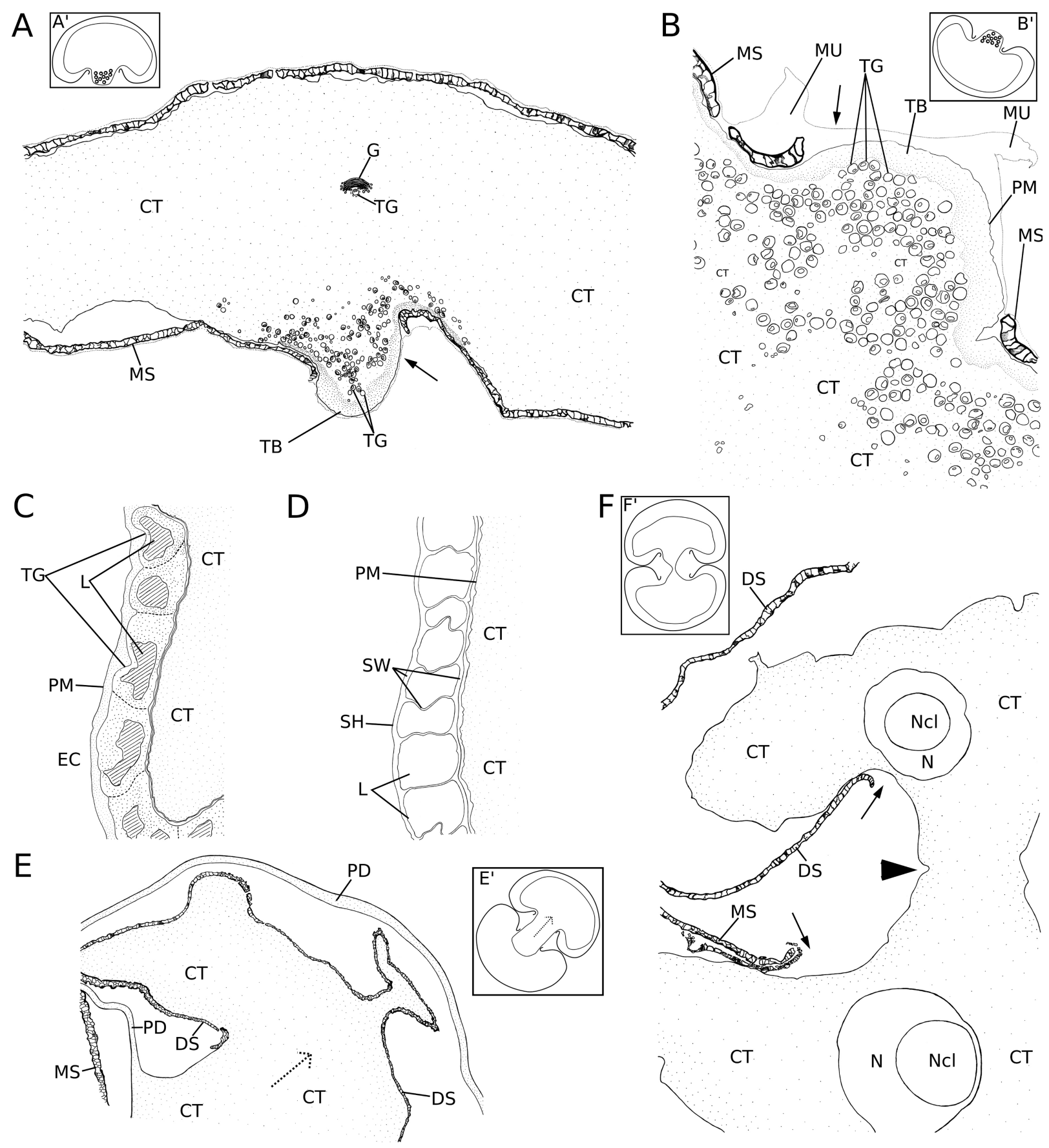

Fig. 2. Reproduction of tangential sections of Arcella during the thecagensis process. A - Formation of the thecagenous bud (TB). The scheme shows the concentration of the thecagenous granules (TG) on the growing bud, near the shell ( $\mathrm{SH}$ ) aperture; these granules are derived from Golgi apparatus $(\mathrm{G})$; the arrow shows the aperture region. Based on the Fig. 4 from Mignot and Raikov (1990); Golgi representation was based on Netzel and Grunewald (1977). A' is a reference map for Fig. A. B - Details of the thecagenous bud (TB) formation and the mucus-like product (MU) secreted shortly before the extrusion of thecagenous granules (TG); the mucus composition is not known. Based on Fig. 5 from Mignot and Raikov (1990). B' is a reference map for Fig. B. $\mathrm{C}$ - Shows the thecagenous granules (TG) organized on a single layer in the edge of the plasma membrane (PM), in a late stage of thecagenesis. The thecagenous granules (TG) have a prominent alveolar lumen (L). Based on Fig. 25B from Netzel and Grunewald (1977). D - Shows the thecagenous material externalized and with defined structure. The alveolar lumen is maintained after the extrusion of the thecagenous material. Based 
conducted detailed studies of exuviation in lineages of Arcella dentata that have two nuclei, although he did not use the term "exuviation" and referred to this process as "empty shell formation" (Hegner 1919, 1920). In those studies, he obtained uni-nucleated specimens by dissection of binucleated individuals and followed their succeeding generations (Hegner, 1919, 1920). Although the process is not completely understood, it has been demonstrated that uni-nucleated specimens of Arcella dentata (that originated from a culture of bi-nucleated individuals) were able to double their nucleus number during exuviation (Hegner, 1920). This process does not have a regular periodicity; many generations of uni-nucleated offspring can develop from a uni-nucleated parent before an exuviation process occurs and an offspring with two nuclei appears (Hegner, 1920). Hegner also described some cases when bi-nucleated specimens were performing exuviation without doubling the number of nucleus, but rarer than uni-nucleated specimens (Hegner, 1920).

Many open questions about the process of empty shell formation remain unresolved, for instance, why the bi-nucleated state is reestablished and why nuclei doubling involves empty shell formation (Hegner, 1920). Moreover, Hegner demonstrated that the morphology of shell formed during exuviation deviates from the average morphology of the lineage (Hegner, 1920). We will discuss the morphological and morphometric variability of empty shells below.

\section{Shell formation process during regeneration}

The formation of a new shell can occur during shell regeneration (Hegner, 1920; Pchelin, 2010; Volkova and Smirnov, 2016). Recently, meticulous experiments have demonstrated that Arcella individuals are capable of regenerating their shell once deprived of it by dissection; the shell formation during regeneration is not followed by cell division (Pchelin, 2010; Volkova and Smirnov, 2016).
Generally, the new shell has abnormal morphology and may not completely cover the cell (Pchelin, 2010; Volkova and Smirnov, 2016). However, the species-specific morphology can fully recover in the succeeding generations (Volkova and Smirnov, 2016). Moreover, these findings suggest a potential role of the shell in the normal development and behavior of Arcella individuals (for details please check Pchelin, 2010, and Volkova and Smirnov, 2016).

\section{Shell structure in Arcella}

The structure of the shell is determined by the intrinsic characteristics of the thecagenous granules and the shell formation process. The surface structure of several Arcella species is described as a regular hexagonal network (or honeycomb-like structure) (Fig. 4 A, B), first noted by Wallich (1864). Later on, this observation was consistently corroborated by other authors (Penard, 1902; Awerintzew, 1907; Cushman and Henderson, 1906; Deflandre, 1928; Cambar et al., 1963; Charret and Vivier, 1964; Moraczewski, 1971; Netzel, 1971, 1975a, 1975b; Netzel and Grunewald, 1977; Mignot and Raikov 1990). According to Rhumbler (1896), the observed external structure of the shell was derived from the nature of its building blocks, spherical drops (Phäasomen). Similarly, other authors proposed that the building blocks should be thin-walled balls (Penard, 1902) or spherical elements (Awerintzew, 1907), which, when juxtaposed, would generate a hexagonal shape (Penard, 1902; Awerintzew, 1907). This idea was further developed by Moraczewski (1971), who proposed that circular alveolus (vesicles) derived from the endoplasmic reticulum (ER) were the units involved in the origin of a honeycomb structure. Netzel (1975a, 1975b) proposed the participation of vesicles (thecagenous granules) as the building blocks of the shell; these thecagenous granules derived from Golgi (i.e. not derived from ER) and were supposed to be directly involved in

on Fig. 26 from Netzel and Grunewald (1977). E - Cytoplasmic flux that shapes the forming shell (daughter shell - DS). The scheme shows the pseudopodial dome (PD), which covers the forming shell (DS). Based on the Fig. 8 from Mignot and Raikov (1990). E' is a reference map for Fig. E. F - Cytokinesis, the last stage of Arcella fission. The figure shows the two shells, the mother and daughter shells (MS and DS, respectively), and the cytokinesis site (arrowhead); the arrows show the aperture region. Based on the Fig. 11 from Mignot and Raikov (1990). F' is a reference map for figure F. Abbreviations: CT - cytoplasm, DS - forming daughter shell, EC - extracellular region, G - Golgi apparatus, MS - mother shell, MU - mucus-like product, secreted shortly before TG secretion, N - nucleus, NCL - nucleolus, PD - pseudopodial dome, SW - shell walls, $\mathrm{TG}$ - thecagenous granules. 
A

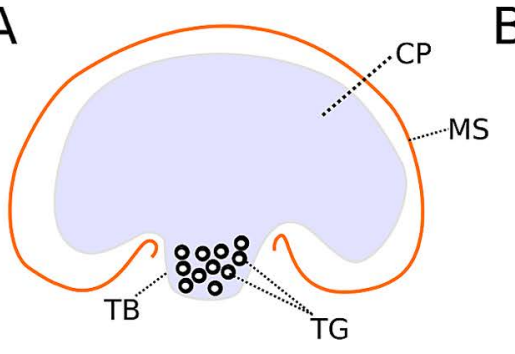

D

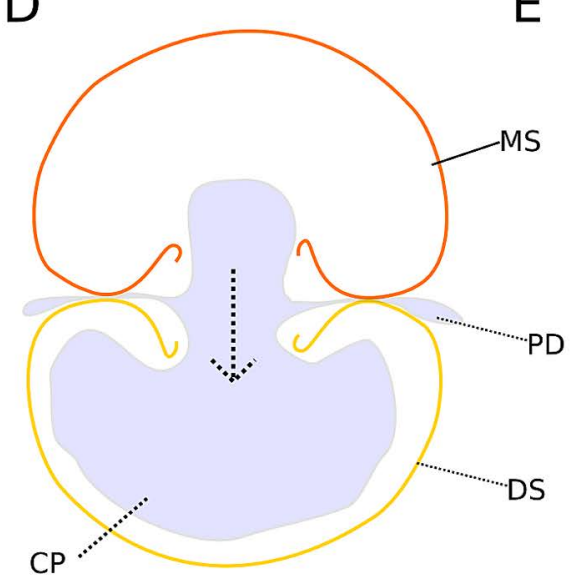

$\mathrm{G}$

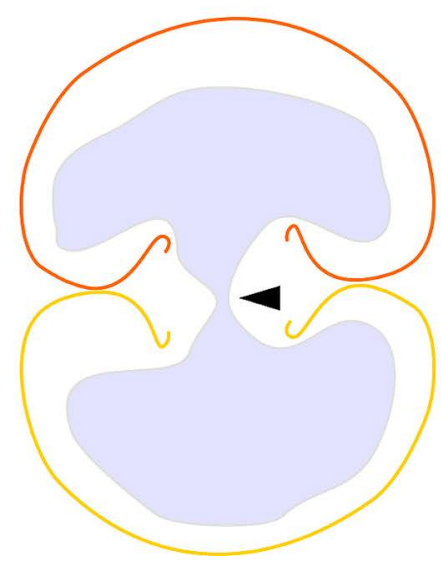

B

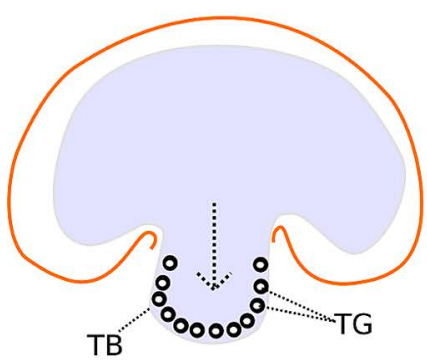

$E$

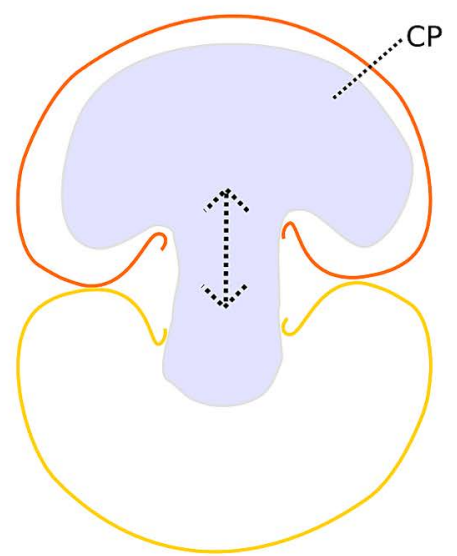

$\mathrm{H}$

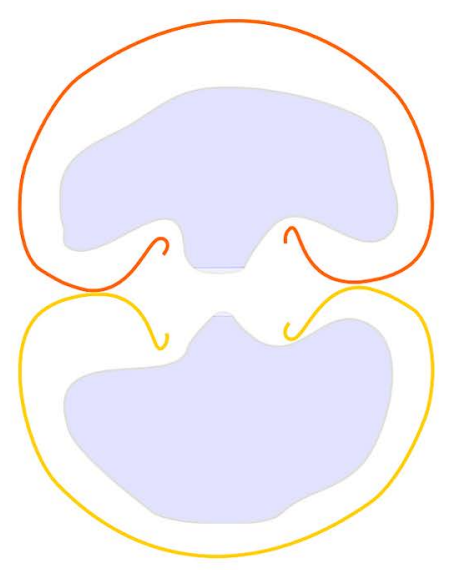

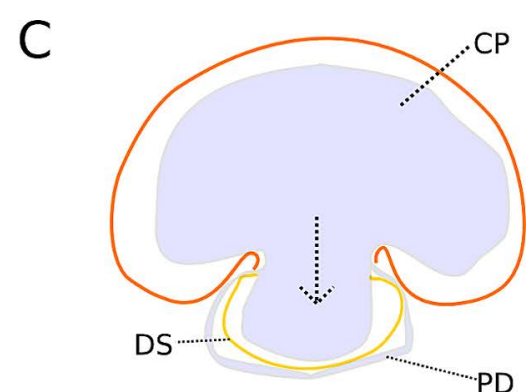

$\mathrm{F}$

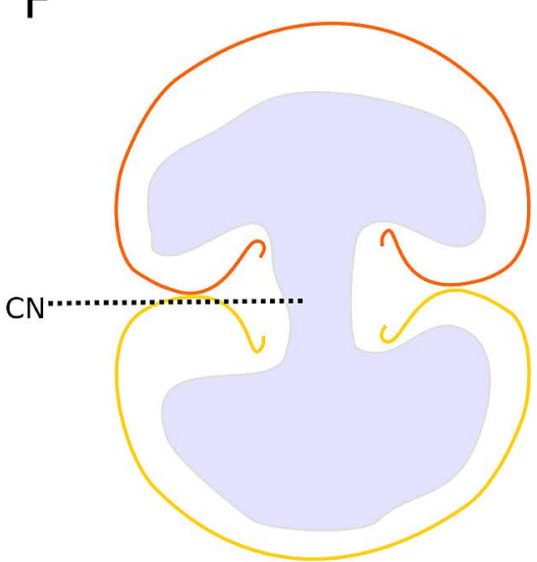

I

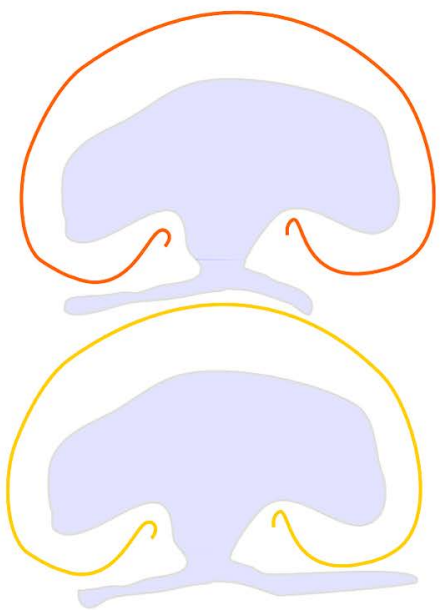

Fig. 3. Representation of shell formation and cell division in Arcella, based on light microscopy observations and video produced by Professor Harald Netzel (Netzel, 1969). A - Thecagenous bud (TB) formation and concentration of thecagenous granules in the edge of the plasma membrane (PM), near to the regions of the mother shell (MS - orange line) aperture. Cytoplasm (light blue) and thecagenous granules (TG) shown. TG are not observable under light microscope, but are shown based on Fig. 5 from Mignot and Raikov (1990). B - Thecagenous bud growth and thecagenous granules arranged on a single layer near the PM. Dashed arrow represents the direction of bud growth. C - The daughter shell (DS - yellowish line) is observed externally. Dashed arrow represents the direction of bud growth and cytoplasmic flux. D - An abrupt growth of the thecagenous bud and cytoplasmic flux determines the general shape of the DS. Dashed arrow represents the direction of bud growth and cytoplasmic flux. E - Intense cytoplasmic flux between both shells is observed. Dashed arrow represents the direction of cytoplasmic flux. F - Cytoplasm equally distributed between the shells, with a cytokinesis neck (CN) present. G - Cell cytokinesis (arrow head). H-I - Two individuals completely formed. 
A

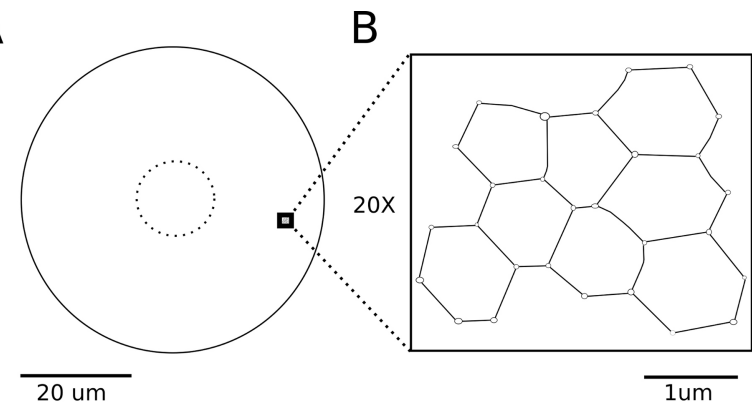

C

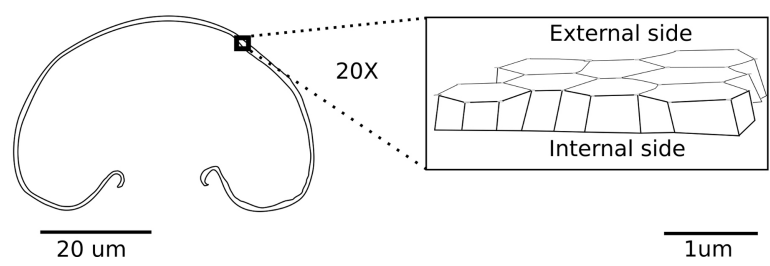

Fig. 4. Schematic representation of general Arcella shell structure, based on scanning electron microscope micrographs of Arcella hemisphaerica from Lahr and Lopes (2009). A - Representation of an intact shell in the apertural view; B - representation of the external hexagonal (honeycomb-like) shell structure of Arcella; C - representation of a tangential section of Arcella shell in side view; $\mathrm{D}$ - representation of the prismatic structure of the shell, based on tangential sections of the shell.

shell formation (Netzel, 1975a, Mignot and Raikov, 1990). Finally, it was demonstrated that the extrusion and juxtaposition of the thecagenous granules, which contain the shell material, generated the hexagonal network aspect of the shell (Netzel, 1975a, 1977; Mignot and Raikov, 1990). The composition of the proteinaceous material that composes the shell is currently unknown.

The tangential section of Arcella demonstrates that the shell is formed by box-like (prism) structures (Fig. 4 C, D). Initially, several authors have described the shell of Arcella as a bi-layer structure (Hertwig and Lesser, 1874; Bütschli, 1875; Penard, 1902; Awerintzew, 1907; Swarczewsky, 1908; Dangeard, 1910); it was thought that each layer was deposited in different moments (Swarczewsky, 1908; Dangeard, 1910). Later, after the proposition that thin-walled balls were the building blocks of the shell (Rhumbler 1896; Penard, 1902; Awerintzew, 1907), Cushman and Henderson (1906) described the shell of Arcella as a single layer of hexagonal juxtaposed prisms; this description was further confirmed by several observations (Deflandre, 1928; Netzel, 1975a; Mignot and Raikov, 1990). Netzel (1975b), and Mignot and Raikov (1990) showed that the thecagenous granules presented an alveolar lumen. Netzel (1975a) also demonstrated that once extruded, the thecagenous granules became juxtaposed and the alveolar lumen was maintained through the thecagenesis process and was present in the mature shell. Thus, in tangential sections, Arcella shells were observed as a single layer of juxtaposed prisms (as shown in Fig. 2 C, D, Fig. 4 C, D).

It is worth noting that some Arcella species deviate from the general external honeycomb-like structure. For instance, the surface of species of the Arcella gibbosa complex and Arcella brasiliensis have roughly hexagonal units or circular units instead of clear hexagonal units as seen in Arcella hemisphaerica and some species of the Arcella gibbosa complex (Lahr and Lopes, 2009). This is a demonstration of the diversity of shell ultrastructural morphology and variability in the general pattern of the shell formation process.

\section{New insights into the shell formation process and current knowledge gaps}

SHELl FORMATION PROCESS, EXUVIATION, AND REGENERATION TRIGGERS

As discussed above, shell formation occurs in different situations: before each cell division, during exuviation or regeneration (Penard, 1902; Hegner, 1919, 1920; Pchelin, 2010; Volkova and Smirnov, 2016). While thecagenesis before cell division or for exuviation are parts of the natural development and life cycle of Arcella, regeneration has been demonstrated through the experiments in which the cells were artificially separated from their shells (Pchelin, 2010; Volkova and Smirnov, 2016). Whether as part of the development or as response to shell deprivation, thecagenesis raises questions about the possible molecular trigger of the process. Similarly, the descriptions of shell regeneration in Arcella lead us to wonder how the cells perceive the absence of the shell. Thus, one of the currently open questions is how the shell formation process is triggered. 
TheCagenous BUd Vs. DIVISION BUD

In the remarkable study of thecagenesis in Arcella dentata (Netzel and Grunewald, 1977), the cell division of some testate amoebae was described as a "budding division" (sensu Schaudinn, 1903) followed by usual binary fission. However, it is well known that arcellinids, as well as the other members of Amoebozoa ("naked" amoebae), perform fission division. The bud formation during shell formation in Arcella and other testate amoebae is a direct consequence of the constriction of the cytoplasm growing through the shell's aperture. Consistently, the bud-like structure observed during shell formation has been treated as a thecagenous bud and is always involved in the thecagenesis process (Mignot and Raikov, 1990). Moreover, as discussed above, not always the shell formation is followed by cell division, for instance, in the exuviation process (Penard, 1902; Hegner, 1919, 1920; Charret, 1964). Thus, the proposed budding-like division (Netzel and Grunewald, 1977) may be explained by a misinterpretation of the temporal overlap between cell division and thecagenesis, since every cell division in testate amoebae is shortly preceded by the formation of a new shell.

THE SHELL INFLUENCE ON THE CYTOPLASMIC ORGANIZATION AND STABILITY

As described earlier, except during the regeneration of a shell-less individual, the formation of a new shell happens through the shell's aperture (Pchelin, 2010; Volkova and Smirnov, 2016). Consequently, the thecagenous granules originated from the Golgi apparatus must be transported to the cytoplasmic region near the shell's aperture. This cytoplasmic region will become the growing thecagenous bud involved in thecagenesis. In this sense, the shell formation process indicates that the cytoplasm of these testate amoebae is organized stably. However, it has not been demonstrated yet how this organization is established and maintained.

It is an accepted knowledge that the testate amoebae have a stably organized cytoplasm; for instance, the nucleus is usually surrounded by the endoplasmic reticulum and localized more distant to the shell aperture, while food vacuoles are distributed between the nucleus and aperture (Netzel, 1975b; Ogden and Hedley, 1980; Volkova and Smirnov, 2016). Recently, it has been demonstrated that the cytoplasmic organization is disrupted in individuals deprived of their shells, resembling that of a naked amoeba (Volkova and Smirnov, 2016). Thus, these observations demonstrate that the cell of Arcella has a stable organization and that the shell possibly has a role in it (Pchelin, 2010; Volkova and Smirnov, 2016). Moreover, it has been suggested that the presence of a shell is mandatory for nucleus and cell division in Arcella, since no shell-less individuals were observed to divide (Pchelin, 2010; Volkova and Smirnov, 2016). Additional studies are necessary to further elucidate the proposed role of the shell in cytoplasmic organization and stability maintenance in testate amoebae (Pchelin, 2010; Volkova and Smirnov, 2016) and, consequently, in the shell formation process.

\section{SHELL MORPHOLOGY AND MORPHOMETRY}

An intriguing aspect related to thecagenesis is the diversity of shell morphology and morphometry among the lineages of Arcella. The genus is recognized by a shell that is circular in apertural view and hemispherical with an invaginated aperture in side view (as represented in Fig. 4), usually with the diameter bigger than the height (Deflandre, 1928). However, several Arcella lineages deviate from this general shape; some species have a more elongated shell in side view (height bigger than diameter), for instance, Arcella mitrata, Arcella apicata, Arcella rukiensis, Arcella nordestina, and Arcella gandalfi (Leidy, 1876; Schaudinn, 1898; van Oye, 1926; Vucetich, 1973; Féres et al., 2016). Diverse lineages of Arcella have shells with depressions or slight folds, instead of a smooth shell, for instance, Arcella artocrea, Arcella gibbosa, Arcella conica, Arcella spectabilis, Arcella arenaria, and Arcella nordestina (Greeff, 1866; Leidy, 1876; Penard, 1890; Playfair, 1918; Deflandre, 1928; Vucetich, 1973). Some lineages have spines in their shells, for instance, Arcella dentata and Arcella rota (Ehrenberg, 1832; Daday, 1905). Furthermore, some lineages have shells with peculiar shapes, such as Arcella excavata that have an oval shell in circular view and croissant-like in side view (Cunningham, 1919; Todorov and Golemansky, 2003). Currently, we lack understanding of the peculiarities of thecagenesis process that gave rise to this diversity of shell shapes in the genus Arcella.

Netzel and Grunewald (1977) pointed out the peculiarity of thecagenesis in $A$. dentata. Although the general processes of shell formation of $A$. dentata and $A$. vulgaris are highly similar, the spine formation in $A$. dentata implies a characteristic pattern. Observations in the apertural view showed that 
during thecagenesis in $A$. dentata different regions of the shell grow unevenly, generating the spines (for detailed description and pictures please check Netzel and Grunewald, 1977). It remains unclear how exactly this uneven growth happens. Similarly, characteristic patterns of thecagenesis from other lineages remain to be elucidated, for instance, it has been questioned how $A$. gandalfi manage to shape its funnel-like shell (Féres et al., 2016).

Alongside the diversity of shapes between different species, intraspecific (i.e. between individuals of the same species or morphospecies) morphological and morphometric variability have been commonly reported for Arcella and other testate amoebae (Schönborn et al., 1983, 1987; Lüftenegger et al., 1988; Lüftenegger and Foissner, 1991; Foissner and Korganova, 1995; Wanner, 1999; Bobrov and Mazei, 2004; Tsyganov and Mazei, 2006; PorfírioSousa et al., 2017). For instance, phenotypic plasticity (i.e. the morphological variation of the same genotype) indicates that the same genotype can build shells with significantly different morphologies depending on the environment (Porfírio-Sousa et al., 2017). The dynamics between thecagenesis and environmental cues expressed as phenotypic plasticity are yet highly unexplored.

Similarly, it has been demonstrated that the shells of Arcella dentata built during empty shell formation (i.e. exuviation) have characteristic morphometry and morphology (Hegner, 1919, 1920). Usually, these shells are built by the dissected specimens with only one nucleus and have, on average, smaller sizes and lesser spines with deviating morphology; after the formation of an empty shell, the specimens reestablish the characteristic binucleated state of the lineage (Hegner, 1920). Based on these observations, Hegner (1920) proposed that empty shell formation is necessary for nucleus doubling and cytoplasmic growth. The deviating morphometry and morphology of the empty shell and the shells of the following generations may be a consequence of a lesser amount of cytoplasm (Hegner, 1920); after some generations, the natural morphology and morphometry of the lineage are fully recovered (Hegner, 1920).

\section{Final considerations}

The literature discussing the thecagenesis process and structure of the shell in Arcella formed a substantial base of knowledge accumulated during the time span of more than a century, with some most productive periods being followed by less productive ones. Currently, we have a comprehensive description of the thecagenesis process and structure of the shell of Arcella in the literature; this description is based on several interpretations and hypotheses proposed by generations of researchers. Some of those hypotheses are not corroborated nowadays; however, their role is important since at certain historical stages they promoted new studies and findings. The use of transmission electron microscopy had a special impact on our current understanding of the problems under discussion. Netzel (Netzel, 1971, 1975a, 1975b, 1980; Netzel and Grunewald, 1977), and Mignot and Raikov (1990) presented a complete description of the thecagenesis process and shell structure in the genus Arcella. These authors established such a comprehensive description by considering the previous literature, generating new data, and deeply describing the cyto-morphology of this process.

In summary, the thecagenesis process is based on: (i) synthesis and accumulation of building material stored in the thecagenous granules; (ii) concentration of thecagenous granules in the cytoplasmic region near the shell aperture; (iii) formation of the thecagenous bud; (iv) arrangement of the thecagenous granules in one layer close to the membrane; (v) synchronous extrusion of the building material to the outer surface of the cell membrane; (vi) cytoplasmic movement giving shape to the new shell, functioning as the mechanical force of morphogenesis of the shell in Arcella. Thus, thecagenesis bases on the underlying characteristic cell features of eukaryotic cells: granules secretion and cytoplasmic flux.

The shell shape (morphology and morphometry) is the main character used to identify the species of testate amoebae; this feature is utilized widely in diverse research fields, such as paleoecology, ecological indication, forensic science, and ecotoxicology (Meisterfeld et al., 2002; Mitchell et al., 2008; Amesbury et al., 2016; Seppey et al., 2016; Amacker et al., 2018). Furthermore, the morphological traits of testate amoebae have evolutionary and ecological significance (Macumber et al., 2020). However, how these organisms manage to maintain or vary these traits through the generations is still a puzzle. A deeper understanding of thecagenesis, including its molecular aspects (e.g. molecular machinery involved in thecagenesis and genes that control the shell traits), may shed light on the morphological inheritance and diversification, as well as contribute to elucidation of how phenotypic plasticity is 
expressed in arcellinids, consequently leading to a more comprehensive evolutionary and ecological understanding of these organisms.

Finally, 43 years ago Netzel and Grunewald made a statement, which is still valid today: “... one must admit, that in thecamoebae these relations [gene products with morphogenesis] are far from clear" (Netzel and Grunewald, 1977). After thirty years since the publication by Mignot and Raikov (1990), followed by the refreshment of the discussion on thecagenesis by Pchelin (2010) and Volkova and Smirnov (2016), it is the high time to establish a molecular framework for Arcella and other testate amoebae by compiling the available cyto-morphological knowledge and coupling it with the generation of new molecular data (i.e. description of thecagenesis in diverse lineages and identification of genes/ molecular apparatus involved in thecagenesis). This research perspective represents a promising framework to be established to clarify a current issue that Deflandre (1953, p. 109) already put in words as "les facultés morphogénétiques de la cellule ... extériorisées" (the cellular morphogenetic faculties ... are externalized [in the shell]). Ultimately, it will be possible to fill the current gaps in the knowledge about the morphogenetic nature of the shell and contribute to the understanding of origin and evolution of this structure in Arcellinida.

\section{Acknowledgments}

We are deeply grateful to Mr. Wilson Soares Júnior for his drawings presented in Fig. 2. We are grateful to MSc Giulia Magri Ribeiro and Dr. Paulo Gonzalez Hofstatter who provided insightful comments on an earlier version of this manuscript. We are in great debt to two anonymous reviewers for their valuable critiques during peer-review. This work was supported by São Paulo Research Foundation (FAPESP) grants 2016/14317-4 and 2017/19388-0 awarded to ALPS and grant 2013/ 04585-3 awarded to DJGL.

\section{References}

Amacker N., Mitchell E.A., Ferrari B.J., and Chèvre, N. 2018. Development of a new ecotoxicological assay using the testate amoeba Euglypha rotunda (Rhizaria; Euglyphida) and assessment of the impact of the herbicide S-metolachlor. Chemosphere. 201, 351-360.
Amesbury M.J., Swindles G.T., Bobrov A., Charman D.J., Holden J., Lamentowicz M., Mallon G., Mazei Y., Mitchell E., Payne R.J., Roland T.P., Turner T.E. and Warner B.G. 2016. Development of a new pan-European testate amoeba transfer function for reconstructing peatland palaeohydrology. Quat. Sci. Rev. 152, 132-151.

Awerintzew S. 1907. Die Struktur und die chemische Zusammensetzung der Gehäuse bei den Siifwasserrhizopoden. Arch. Protistenkd. 8, 95.

Bobrov A. and Mazei Y. 2004. Morphological variability of testate amoebae (Rhizopoda: Testacealobosea and Testaceafilosea) in natural populations. Acta Protozool. 43 (2), 133-146.

Bütschli O. 1875. Zur Kenntniss der Fortpflanzung bei Arcella vulgaris Ehrb. Arch. Mikrosk. Anat. 11 (1), 459-467.

Cambar R., Thomas R. and Le Blanc M. 1963. Recherches sur la constitution de la thèque des Arcelles (Genre Arcella, Rhizopode testacé), observations au microscope électronique. Comptes rendus de l'Académie des Sciences. 256, 1364-1367.

Charret R. and Vivier E. 1964. Ultrastructure de Arcella polypora Rhizopoda Testacea. III Europ. reg. conf. El. Micr. Vol. B, 187-188.

Charret R. 1964. Contribution al'étude cytologique et biologique de Hyalosphenia papilio (Leidy), Rhizopode Testacé. Bull. Biol. Fr. Belg. 98 (2), 369-390.

Charret R. 1967. Caractères cytologiques du Thécamoebien Arcella polypora. Protistologica. 3 (1), 73-78.

Cunningham B. 1919. Arcella excavata nov. sp. Trans. Amer. Micr. Soc. 38, 242-243.

Cushman J. A. and Henderson W.P. 1906. A preliminary study of the finer structure of Arcella. Am. Nat. 40 (479), 797-802.

Daday J. 1905. Untersuchungen über die Süsswasser-Mikrofauna Paraguays: Zoologica. 18 (part 44), 1-374.

Dangeard P.A. 1910. Etudes sur le developpement et la structure des organismes inferieurs. I. Les Amibes. Le Botaniste.11, 4-57.

Deflandre G. 1928. Le genre Arcella Ehrenberg. Arch. Protistenkd. 64 (1), 152-287.

Deflandre G. 1953. Ordres des Testaceolobosa (de Saedeleer, 1934), Testaceafilosa (de Saedeleer, 1934), Thalamia (Haeckel, 1862) ou Thecamoebiens (Auct.) (Rhizopoda Testacea). Traité Zool. 1, 97-148.

Ehrenberg C.G. 1830. Beiträge zur Kenntnis der Organisation der Infusorien und ihrer geographischen Verbreitung, besonders in Sibirien. Abhand- 
lungen der Königlichen Akademie der Wissenschaften zu Berlin. 1-88.

Féres J.C., Porfirio-Sousa A.L., Ribeiro G.M., Rocha G.M., Sterza J.M., Souza M.B.G., Soares C.E.A. and Daniel J.G. 2016. Morphological and morphometric description of a novel shelled amoeba Arcella gandalfi sp. nov. (Amoebozoa: Arcellinida) from Brazilian continental waters. Acta Protozool. 55 (4), 221-229.

Foissner W. and Korganova G.A. 1995. Redescription of three testate amoebae (Protozoa, Rhizopoda) from a Caucasian soil: Centropyxis plagiostoma Bonnet et Thomas, Cyclopyxis kahli (Deflandre) and $C$. intermedia Kufferath. Arch. Protistenk. 146 (1), 13-28.

Greeff R. 1866. Ueber einige in der Erde lebende Amöben und andere Rhizopoden. Arch. Mikrosk. Anat. 2, 299-331.

Hegner R.W. 1919. Heredity, variation, and the appearance of diversities during the vegetative reproduction of Arcella dentata. Genetics. 4 (2), 95.

Hegner R.W. 1920. The relations between nuclear number, chromatin mass, cytoplasmic mass, and shell characteristics in four pieces of the genus Arcella. J. Exp. Zool. 30 (1), 1-95.

Hertwig R. and Lesser E. 1874. Über Rhizopoden und denselben nahestehende Organismen. Arch. Mikrosk. Anat. Suppl. 10, 35-243.

Kosakyan A., Gomaa F., Lara E. and Lahr D.J. 2016. Current and future perspectives on the systematics, taxonomy and nomenclature of testate amoebae. Eur. J. Protistol. 55, 105-117.

Lahr D.J.G. and Lopes S.G.B.C. 2009. Evaluating the taxonomic identity in four species of the lobose testate amoebae genus Arcella Ehrenberg, 1832. Acta Protozool. 48 (2), 127-142.

Leidy J. 1876. Observations on Rhizopods. Proc. Acad. Nat. Sci. Phil. 3rd seri. 28, 197-199.

Lüftenegger G., Petz W., Berger H., Foissner W. and Adam H. 1988. Morphologic and biometric characterization of twenty-four soil testate amoebae (Protozoa, Rhizopoda). Arch. Protistenkd. 136 (2), 153-189.

Lüftenegger G. and Foissner W. 1991. Morphology and biometry of twelve soil testate amoebae (Protozoa, Rhizopoda) from Australia, Africa and Austria. Bull. Brit. Mus. Nat. Hist. (Zool. Ser.). 57, 1-16.

Macumber A.L., Blandenier Q., Todorov M., Duckert C., Lara E., Lahr D.J., Mitchell E.A.D., and Roe H.M. 2020. Phylogenetic divergence within the Arcellinida (Amoebozoa) is congruent with test size and metabolism type. Eur. J. Protistol. 72, DOI: 10.1016/j.ejop.2019.125645

Meisterfeld R. 2002. Order Arcellinida Kent, 1880. In: An Illustrated Guide to the Protozoa (Eds: Lee J.J., Leedale G.F. and Bradbury P.) Lawrence, Kansas, U.S.A., pp. 827-860.

Mignot J.P. and Raikov I.B. 1990. New ultrastructural data on the morphogenesis of the test in the testacean Arcella vulgaris. Eur. J. Protistol. 26 (2), 132-141.

Mitchell E.A., Charman D.J. and Warner B.G. 2008. Testate amoebae analysis in ecological and paleoecological studies of wetlands: past, present and future. Biodivers. Conserv. 17 (9), 2115-2137.

Moraczewski J. 1971. Structure et formation de la coque d'Arcella. Acta Protozool. 8 (27-33), 423-438.

Netzel H. 1969. Morphogenese und Fortpflanzung beschalter Amöben (Testacea). IWF. https:// doi.org/10.3203/IWF/C-1059.

Netzel H. 1971. Die Schalenbildung bei der Thekamöben-Gattung Arcella (Rhizopoda, Testacea). Cytobiologie. 3, 89-92.

Netzel H. 1975a. Die Entstehung der hexagonalen Schalenstruktur bei der Thekamöbe Arcella vulgaris var. multinucleata (Rhizopoda, Testacea). Arch. Protistenkd. 117, 321-357.

Netzel H. 1975b. Struktur und Ultrastruktur von Arcella vulgaris var. multinucleata (Rhizopoda, Testacea). Arch. Protistenkd. 117, 219-245.

Netzel H. 1980. Amöben als Baumeister. Biologie in unserer Zeit. 10 (6), 183-190.

Netzel H. and Grunewald, B. 1977. Morphogenesis in shelled rhizopod Arcella dentata. Protistologica. 13 (2), 299-319.

Ogden C.G. and Hedley R.H. 1980. An Atlas of Freshwater Testate Amoebae: British Museum of Natural History and Oxford University Press. London and Oxford, UK.

Pchelin, I. M. 2010. Testate amoeba Arcella vulgaris (Amoebozoa, Arcellidae) is able to survive without the shell and construct a new one. Protistology. 6 (4), 251-257.

Penard M.E. 1890. Études sur les Rhizopodes d'eau douce. Imprimerie Aubert-Schuchardt.

Penard E.P. 1902. Faune rhizopodique du bassin du Léman. Henry Kündig, Genève.

Playfair G.I. 1918. Rhhizopods of Sydney and Lismore. Proc. Linn. Soc. N. S. W. 42, 633-675.

Porfírio-Sousa A.L., Ribeiro G.M. and Lahr D.J. 2017. Morphometric and genetic analysis of Arcella intermedia and Arcella intermedia laevis (Amoebozoa, 
Arcellinida) illuminate phenotypic plasticity in microbial eukaryotes. Eur. J. Protistology. 58, 187-194.

Rhumbler L. 1896. Beitrfige zur Kenntnis der Rhizopoden. Z. wiss. Zool. 61, 118-126.

Schaudinn F. 1898. Rhizopoda Ost-Afrikas: in: "Deutsch-Ost Afrika", v. 4: Die Thierwelt DeutschOstafriks und der Nachbargebeite. Wirbellose Thiere. 18, 1-13.

Schaudinn F. 1903. Untersuchungen über die Fortpflanzung einiger Rhizopoden. I. Polystomella crispa. In: Fritz Schauddinns Arbeiten. 1911. Hamburg, L. Voss, pp. 499-501.

Schönborn W., Foissner W. and Meisterfeld R. 1983. Licht und rasterelectronenmikroskopische Unter suchungen zur Schalenmorphologie und Rassenbildung bodenbewohnender Testaceen (Protozoa: Phizopoda) sowie Vorschlqge zur biometrischen Characterisierung von Testaceen Schalen. Protistologica. 19, 553-566.

Schönborn W., Petz W., Wanner M. and Foissner W. 1987. Observations on the morphology and ecology of the soil-inhabiting testate amoeba Schoenbornia humicola (Schönborn, 1964) Decloitre, 1964 (Protozoa, Rhizopoda). Arch. Protistenkd. 134 (4), 315-330.

Seppey C.V., Fournier B., Szelecz I., Singer D., Mitchell E.A. and Lara E. 2016. Response of forest soil euglyphid testate amoebae (Rhizaria: Cercozoa) to pig cadavers assessed by high-throughput sequencing. Int. J. Med. Toxicol. Legal Med. 130, 551-562.
Swarczewsky B. 1908. Über die Fortpflanzungserscheinungen bei Arcella vulgaris Ehrbg. Arch. Protistenkd. 12, 173-212.

Todorov M. and Golemansky V. 2003. Morphology, biometry and ecology of Arcella excavata Cunningham, 1919 (Rhizopoda: Arcellinida). Acta Protozool. 42 (2), 105-112.

Tsyganov A. and Mazei Y. 2006. Morphology and biometry of Arcella intermedia (Deflandre, 1928) comb. nov. from Russia and a review of hemispheric species of the genus Arcella (Testcealobosea, Arcellinida). Protistology. 4 (4), 361-369.

van Oye P. 1926. Six Rhizopodes nouveaux du Congo Belge. Arch. Zool. Exp. Gén. 65, 64-74.

Volkova E. and Smirnov A. 2016. Regeneration of test in testate amoebae of the genus Arcella $(\mathrm{Tu}-$ bulinea, Arcellinida). Eur. J. Protistol. 55, 128-140.

Vucetich M.C. 1973. Estudio de tecamebianos argentinos en especial los del dominio pampasico. Revista del Museo de la Plata. 11 (108), 287-332.

Wallich G.C. 1864. On the extent, and some of the principal causes, of structural variation among the Difflugian Rhizopods. Ann. Mag. Nat. Hist. Ser. 3. 13 (75), 215-245.

Wanner M. 1999. A review on the variability of testate amoebae: methodological approaches, environmental influences and taxonomical implications. Acta Protozool. 38 (1), 15-29.

Address for correspondence: Daniel J.G. Lahr. Department of Zoology, Institute of Biosciences, University of São Paulo, Brazil; e-mail: dlahr@ib.usp.br. 